\title{
Global poverty is ours to reject
}

$\mathrm{C}$ anada is a wealthy country and a comfortable place to live. In contrast, much of the world is poverty stricken and is an uncomfortable place to die. This difference is the greatest single challenge, in medicine or any other discipline, of our lifetime.

In this issue, CMAJ focuses on poverty and human development as part of a global initiative by the Council of Science Editors. More than 200 scientific journals have agreed to publish articles on this theme during October. Why take the struggle to medical journals? Because if global poverty is to be shifted, then a sea change in thinking is needed - one in which Canadian doctors have an indispensable role as proxy voices for the world's poorest people.

The global development establishment works on quite a simple model: there are rich "donor" nations and poor "recipient" nations. Donor nations almost never give enough money. In 2005 , Canada gave about $\$ 4.6$ billion, or $0.34 \%$ of its gross domestic product - less than the $0.49 \%$ once given by Canada or the $0.7 \%$ that Canadian governments have promised for decades (the average is $0.47 \%$ for other Organisation for Economic Co-operation and Development donor countries). ${ }^{1}$ But much of what the donors give is also spent in self-defeating ways, such as by saddling the recipients with overbearing conditions, arm-twisting recipients to buy the donor nation's goods or services, financing medically obsolete interventions or, contrary to common sense, sponsoring dictatorial or kleptocratic recipients for ulterior geopolitical objectives.

There have been whole books written about these problems. Some recommend zealously to spend more money on reducing poverty - which is correct. Others complain wearily that the institutions responsible for reducing poverty have squandered money they were given - which is also correct. What to do?

The least headache-provoking answer to this question is to chance nothing. Such aversion might explain why this spring, Steven Harper's government quietly slashed several hundred million dollars off an aid commitment made to Africa 2 years ago. ${ }^{2}$ The prime minister complains that the aid business is too unaccountable. It would have been better if he engineered that accountability, rather than staunch Canada's already feeble aid contributions, given that about I billion people worldwide (about 30 times Canada's population) barely survive on $\$$ I a day or less.

Even so, Mr. Harper is correct: the aid establishment is too unaccountable. One could say the aid establishment is its own worst enemy because politicians will always be wary of putting in the needed extra billions of dollars so long as they lack confidence in the aid establishment's methods, transparency and results. We outline here an agenda for change.

A large and inexcusable problem is that international aid is hardly evidence based. Instead, it tends to be dictated by the master plans of bureaucracies in Washington, New York and Geneva. The donors all claim to get buy-in from local partners for their plans, but the endorsement is almost always post hoc, and few aid-dependent recipients dare withhold the required rubber stamp. Too often, central planning and coercion eclipse the scientific, economic and sociologic evidence.

For example, in Africa and Asia, UNICEF, the World Bank and the Global Fund to Fight AIDS, Tuberculosis and Malaria bought chloroquine as treatment for deadly falciparum malaria, despite being warned by the World Health Organization (WHO) that chloroquine was not recommended. These agencies provided chloroquine, even when evidence showed that treatment failed in up to $80 \%$ of cases because of drug resistance. Aid recipients wanted the better, WHO-recommended medicines (i.e., artemisinin combination therapy), but they were powerless to stand up to donors who balked at paying for "expensive" treatments costing under \$2. Delays in the processes of changing and raising the standard of care to artemisinin combination therapies, which are ongoing, have cost hundreds of thousands, or possibly millions, of lives.

In the research domain, medical malpractice of this kind is avoided because projects must survive both peer review and ethics board review. Not so in development aid. Most donors have no peer-review process and spotty or no ethics board review. Yet compared with typical clinical trials, projects funded by donors often impact orders of magnitude more people.

Hand in glove with disregard for evidence is a lack of openness. Go to the Canadian International Development Agency (CIDA) website and try to find the processes, forms and deadlines to apply for project funding. But don't spend too long trying because except for some minor programs such as conferences, there are none. Most of the $\$ 3$ billion the Canadian International Development Agency will spend this year is allocated without a formal application and competition processes to ensure that poverty-reduction plans use the best scientific, economic and sociologic evidence. Instead, money is often given out based on "connections" or for objectives far removed from poverty reduction.

One such depredation is a program tellingly called the Industrial Cooperation Program (CIDA-INC). This program grants funding to Canadian companies to start a business or to provide training in developing countries. The program's beneficiaries include a Quebec firm that opened a jointventure plastics factory in Egypt. Thanks to Canadian tax money and technology, the Canadian International Development Agency reports the factory is making "diving piers, saltwater open-concept swimming pools and many other products used extensively in marinas of hotels and seaside resorts." ${ }^{3}$

This isn't poverty reduction: it's corporate welfare. Certainly it is desirable for the Canadian International Development Agency and corporations to work cooperatively, but the 
review process has to select only partnerships that primarily aid the world's poorest people, not the manufacturers or users of fancy swimming pools.

Canada and the Canadian International Development Agency should follow the example of Britain's donor agency. Britain's Parliament passed a law requiring aid funds to be spent on poverty reduction exclusively and prohibiting favouritism of British corporations. ${ }^{4}$ Some now say that Britain's aid agency, which was scandal ridden in the Iggos, is the world's best. It would be exceedingly easy for the Harper government to copy Britain's law and to pass it here in Canada.

But even with a reformed Canadian International Development Agency, there remains a further challenge. In Europe and the United States, there is an extensive brain trust focused on providing research and ideas for international development, but in Canada most of that expertise has emigrated for lack of support. Our inability to hold on to the best and brightest who want to dedicate themselves to poverty reduction is tragic. Canadians excel in sciences such as epidemiology that are pivotal to solving the causes of poverty. Canadian researchers need funding to apply their skills to poverty reduction and a career track to train a new generation.

To begin with, Canada should properly fund one or more bespoke institutes of global public health and medicine. Such tropical medicine schools (as they are quaintly called) exist in Belgium, Britain, Denmark, France, Germany, Italy, the Netherlands, Switzerland and the United States. Canada has no such schools, and the signal this sends is that Canada is picayune and uninterested in the health of billions of people. Establishing a bilingual graduate school of global public health and medicine is a logical step and an excellent act of public diplomacy to boast about in both the Commonwealth and La Francophonie.

Canada also must stop underfunding global public health and medicine research. Five years ago, the Canadian Institutes of Health Research, the Canadian International Development Agency and the International Development Research Centre launched the Global Health Research Initiative. Yet a forthcoming study by researchers at the University of Ottawa shows that Global Health Research Initiative funding in the ensuing years has been only about $\$ 40$ million - or less than \$ro million annually (Vivian Robinson, University of Ottawa, Ottawa, Ont.: personal communication, 2007).

By comparison, just one charity, the Bill and Melinda Gates Foundation, has on several occasions awarded one-off grants that exceed the total Global Health Research Initiative research budget over 5 years.
When the GI (Gates Foundation) outspends a G8 government of 33 million people, it proves Canada is not even trying. When he was prime minister, Paul Martin promised and failed to spend $5 \%$ of Canada's research budget on the study of global poverty - or about \$10o million annually. That is a promise that Mr. Harper should poach and implement.

The CMAJ believes these easy steps can, within a decade, make Canada a leader in global health and poverty reduction. The trouble is, poor Africans, Asians and Latin Americans who live in hunger, ill health, fear and poverty are not a constituency who vote in Canada, so getting political traction in Ottawa is hard. Thus, we recommend that every doctor who cares about these issues form a proxy constituency, by volunteering a little time to campaign groups focused on poverty groups such as Results-Résultats Canada, which coordinates doctors and others to lobby government to do more about malaria, immunization, sanitation and tuberculosis. Many other groups, some of which are well known, such as Médecins Sans Frontières, and some you may not know, are both campaigning and intervening on these problems. ${ }^{5}$ There is not a doctor in this country who, no matter how busy, cannot find a few minutes to join such efforts and to raise his or her caregiving to the fight on global poverty - which is definitely the most profound social problem of our time.

\section{Amir Attaran LLB DPhil}

Canada Research Chair in Law, Population Health and Global Development Policy

University of Ottawa

Ottawa, Ont.

With the Editorial-Writing Team (Paul C. Hébert MD MHSc, Matthew B. Stanbrook MD PhD, Barbara Sibbald BJ, Ken Flegel MDCM MSc and Noni MacDonald MD MSc)

\section{REFERENCES}

I. Organisation for Economic Co-operation and Development. Statistical annex of the 2006 development co-operation report. Paris: The Organisation; 2007. Available: www.oecd.org/dac/stats/dac/dcrannex (accessed 2007 Sept 2I).

2. Freeman A. Impoverished Africa loses out in a war of words. Globe and Mail [Toronto] 2007 June I6;Sect F:3.

3. Canadian International Development Agency. Casting a new mould in Egypt. Gatineau (Que): The Agency; 2007. Available: www.acdi-cida.gc.ca/CIDAWEB lacdicida.nsf/En/ANN-62215107-QGV?OpenDocument (accessed 2007 Sept 2I).

4. Barder O. Reforming development assistance: lessons from the UK experience. Center for Global Development Working Paper [number 70]. Washington: The Center; 2005. Available: www.cgdev.org/files/437I_file_WP_70.pdf (accessed 2007 Sept 2I).

5. Bryden L. Getting involved: donating time, money and expertise to global health. CMAJ 2007; I77:I020-I. 